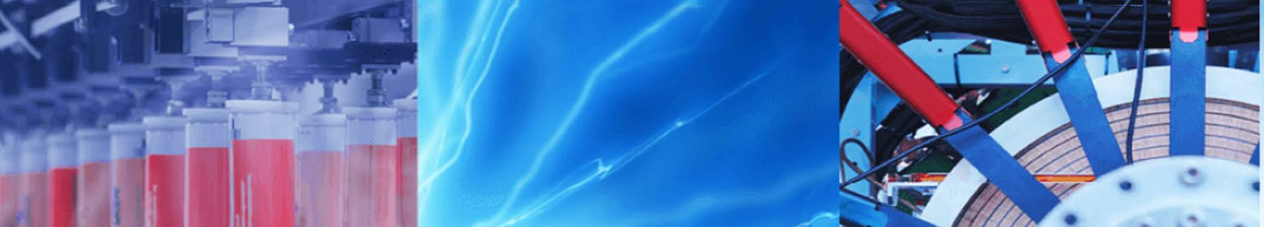

Research Article

\title{
Influence of redox mediators and media on methyl red decolorization and its biodegradation by Providencia rettgeri
}

\author{
Olumide Olukanni ${ }^{1} \cdot$ Ayodeji Awotula ${ }^{2,3} \cdot$ Akinniyi Osuntoki $^{3} \cdot$ Sanjay Govindwar ${ }^{4}$
}

(c) Springer Nature Switzerland AG 2019

\begin{abstract}
Developing efficient, effective and low-cost procedure for color removal in wastewater is a serious environmental concern. In this study, we investigated the possibility of enhancing the activities of dyes decolorizing bacterium using selected redox mediators and media (nutrient broth, yeast, glucose, starch and peptone). The isolated organism identified using $16 \mathrm{~S}$ rRNA gene as Providencia rettgeri showed the highest decolorization of a model dye, methyl red by $97 \%$ within $6 \mathrm{~h}$ using nutrient broth. Preferred redox mediator was found to be quinol ( $95 \%$ within $5 \mathrm{~h}$ ) than other (nicotinamide adenine dinucleotide $\left(\mathrm{NAD}^{+}\right)$, reduced $\mathrm{NAD}^{+}$, nicotinamide adenine dinucleotide phosphate $\left(\mathrm{NADP}^{+}\right)$and reduced $\mathrm{NADP}^{+}$). In addition, the biodegradation of methyl red was investigated by subjecting its metabolites to UV-visible, highperformance liquid chromatography and Fourier transform infrared analyses that suggested the biodegradation. This was confirmed by the removal of signature peaks of aromatic $\mathrm{C}-\mathrm{H}$ bending $\left(645,759\right.$ and $\left.831 \mathrm{~cm}^{-1}\right)$ and the $\mathrm{N}=\mathrm{N}$ peak at $1509 \mathrm{~cm}^{-1}$ of the FTIR spectrum of the metabolites. In conclusion, introduction of minute amount of hydroquinone $(1 \mathrm{mM})$ into wastewaters could enhance their biotreatment by this strain of $P$. rettgeri.
\end{abstract}

Keywords Biodegradation $\cdot$ Decolorization $\cdot$ Methyl red $\cdot$ Providencia rettgeri $\cdot$ Redox mediators

\section{Introduction}

Industrialization is vital for a nation's economic development, but it is equally associated with the production of life-threatening effluents. Such effluents contain enormous amounts of dyestuffs, which rendered them aesthetic displeasing and environmentally harmful [1]. About $15 \%$ of dyestuffs used in industries entered into the effluents [2]. Approximately 10,000 different dyes and pigments are used industrially, and over 0.7 million tons of synthetic dyes are produced annually worldwide. These colored wastewaters, which are often discharged into nearby streams and rivers, have adverse effects on the ecosystem. They alter the $\mathrm{pH}$ and increase the biochemical oxygen demand (BOD) and chemical oxygen demand
(COD) of the receiving water bodies [3]. This alteration in the physicochemical parameters of the aquatic bodies results in hardships of aquatic life and bioaccumulation of toxic compounds. Worse still, synthetic dyes in wastewaters are usually obstinate to most treatment processes. Prominent among these synthetic dyes are the azo dyes.

Azo dyes are the major textile dyestuffs produced, and they are the most commonly used synthetic dyes in the textile, food, printing, leather, cosmetics and papermaking industries [4]. More than 800,000 tons of these dyes are produced annually worldwide [5]. In addition to the coloration of water bodies, many synthetic azo dyes are known to be toxic, carcinogenic and genotoxic $[6,7]$. Furthermore, they reduce the dissolved oxygen in waters, thus making aquatic life difficult [8]. Azo dyes are

Olumide Olukanni, olukannio@run.edu.ng | 'Department of Biochemistry, College of Basic Medical Sciences, Redeemer's University, Gbongan Osogbo Road, P.M.B. 230, Ede, Osun State, Nigeria. ${ }^{2}$ Department of Biological Sciences, McPherson University, Seriki Sotayo, P.M.B. 2094, Abeokuta, Ogun State, Nigeria. ${ }^{3}$ Department of Biochemistry, College of Medicine, University of Lagos, P.M.B. 12003 , Lagos, Nigeria. ${ }^{4}$ Department of Earth Resources and Environmental Engineering, Hanyang University, Seoul 04763, South Korea.

SN Applied Sciences (2019) 1:697 | https://doi.org/10.1007/s42452-019-0668-0 
a group of compounds characterized by the presence of one or more azo bonds $(-\mathrm{N}=\mathrm{N}-)$ in association with one or more aromatic systems [9]. This chemical nature makes them relatively resistant to most biological and chemical treatments.

Conventional wastewater treatment processes are not usually efficient to remove recalcitrant dyestuffs, like azo dyes, from effluents; and physicochemical methods such as adsorption, chemical precipitation, photolysis, chemical oxidation and reduction, electrochemical treatment have been found worrisome due to high cost, low efficiency, production of secondary pollutants and nonsuitability for a variety of dyes [10]. These disadvantages make biological treatments of the wastewater containing dyes, such as microbial or enzymatic decolorization and degradation, a viable alternative. Several microbial enzymes are being used for azo dye degradation which require redox mediators. Presently, nanoparticle-microbial enzyme conjugate-mediated degradation of textile azo dyes is on top in global scenario for specific substrates [11]. Although biotreatment of wastewater has been adjudged to be more eco-friendly, cheaper and safer alternative to chemical decomposition process [12], there is a need to optimize the processes.

There are dwindling but promising results of accelerating dye decolorization by adding mediating compounds or changing process conditions [13]. Dos-Santos et al. [14] have shown acceleration of azo dye reduction by the addition of a redox mediator-anthraquinone sulfonate. Studies have also demonstrated that ubiquitous sources of electrons, such as reduced forms of nicotinamide adenine dinucleotide (phosphate) (NAD $(\mathrm{P}) \mathrm{H})$, were able to reduce azo dyes, even in the absence of microbes or enzymes [15]. Another extracellular reducing agent-sulfide - produced via respiration by sulfatereducing bacteria has been shown to decolorize azo dyes chemically [16, 17]. Van der Zee and Villaverde [18] have also reported that the initial step in the biodegradation of azo dyes is the cleavage of the azo bond, a reaction catalyzed by the enzyme azoreductase. Azoreductases generally require $\mathrm{NAD}(\mathrm{P}) \mathrm{H}$ for their catalytic activities.

Another way of increasing the rate of decolorization is the choice of media. Studies with dyes as the sole source of carbon usually take prolonged time, some taken days or weeks. In previous decolorization studies, involving the use of minimal media, the percentage decolorization was low, the highest being $47 \%$ after 14 days of incubation [3]. This study emphasizes the importance of media choice in bacterial decolorization of color effluents.

The objective of our study was thus to investigate the possibilities of selected chemical mediators and different media to increase the removal of azo dyes in wastewater.
The biodegradation of the dye as against mere decolorization was also studied.

\section{Materials and methods}

\subsection{Dyes and chemicals}

Methyl red (MR) and hydroquinone were products of $\mathrm{BDH}$ chemicals (Poole, England), and nicotinamide adenine dinucleotide $\left(N A D^{+}\right)$, reduced $N A D^{+}$, nicotinamide adenine dinucleotide phosphate $\left(\mathrm{NADP}^{+}\right)$and reduced $\mathrm{NADP}^{+}$ were from Sigma Chemical Co. (St. Louis, Mo, USA). Nutrient broth and agar were those of Lab M Ltd. (Lancashire, UK). Other reagents were of analytical grade.

\subsection{Screening, isolation and identification of the bacterium}

Isolation of bacteria from technical grade dyes was carried out by the enrichment technique using nutrient broth and a mixture of three dyes: Reactive Blue 13, Reactive Yellow 42 and Reactive Red 58 at 50 mg/L concentration. The decolorized broth was cultured on nutrient agar, and isolates from pure colonies were tested for decolorization ability. One of the prominent decolorizers was chosen and identified using the morphological, biochemical and genetic method. The genetic identification, using $16 \mathrm{~S}$ rRNA gene sequence of the strain, was done at geneOmbio, Pune, India. The sequence was then analyzed at NCBI server (http://www.ncbi.nlm.nih.gov) and deposited at GenBank. The phylogenetic analysis of the sequence was done using MEGA 4 [19]. The organism was maintained on a nutrient agar slant at $4{ }^{\circ} \mathrm{C}$ and proliferated in $250 \mathrm{~mL}$ Erlenmeyer flask containing $13 \mathrm{~g} / \mathrm{L}$ of nutrient broth at room temperature until its turbidity $\left(\mathrm{OD}_{600}\right)$ is about 1.0 prior every experiment. The nutrient agar contains $(\mathrm{g} / \mathrm{L})$ : peptone, 5; beef extract, 3; NaCl and agar No.2, 12, while the composition of the nutrient broth $(\mathrm{g} / \mathrm{L})$ was beef extract, 1; yeast extract, 2; peptone, 5 and $\mathrm{NaCl}, 5$.

\subsection{Decolorization at various dye concentrations}

Decolorization experiments were performed in triplicates, and abiotic controls (without microorganism) were included in all experiments. A fresh sterile nutrient broth was prepared with the sterile dye sample to a concentration of $13 \mathrm{~g}$ nutrient broth per liter of media. Portions of the broth $(2 \mathrm{~mL})$ of overnight culture were added into $50 \mathrm{~mL}$ dye-media solution. The culture media (inoculated dye) were incubated at $30^{\circ} \mathrm{C}$, and $3 \mathrm{~mL}$ of samples was taken at 1-h interval and centrifuged at 4000 r.p.m. for $25 \mathrm{~min}$ to remove cells. The absorbance of the cell-free 
supernatant sample was measured at the dye's predetermined maximum absorbance-wavelength $\left(\lambda_{\max }\right), 482 \mathrm{~nm}$, and percentage decolorization is calculated as:

$\%$ Decolorization $=\frac{A_{\mathrm{o}}-A_{\mathrm{t}}}{A_{\mathrm{o}}} \times 100$

where $A_{\mathrm{o}}$ is absorbance of the dyes solution and $A_{\mathrm{t}}$ is absorbance of the treated dyes solution at a specific time, $t$. The experiment was repeated for the dye at 20, 30, 50, 100 and $200 \mathrm{mg} / \mathrm{L}$.

\subsection{Effect of various media on the decolorization of MR}

The effect of media composition on decolorization was investigated by adding five nutrient sources into different MR solutions: nutrient broth, NB; with yeast extract, YS; with glucose, GC; with peptone, $\mathrm{PT}$; with starch, SR (13 g/L each). The media were sterilized at $121^{\circ} \mathrm{C}$ for $15 \mathrm{~min}$. Percentage decolorization was determined as described above. Medium with the highest decolorization activities was used for the mediator experiments.

\subsection{Effect of selected redox mediators on decolorization of MR}

The ability of redox mediators: quinol, NAD, NADH, NADP and NADPH to influence the decolorization of the azo dye MR was investigated using $1 \mathrm{mM}$ [20] of the mediators in different vessel containing $50 \mathrm{~mL}$ of the dye-broth solution. The choice of these mediators was born out of their importance in biochemical processes and as cofactors for enzymes. An equal amount of the organism ( $0.05 \mathrm{~g} \mathrm{DCM})$ was added to each reaction setup.

\subsection{Biodegradation studies}

The biodegradation studies were monitored using the Fourier transform infrared (FTIR) and the high-performance liquid chromatography (HPLC) of the dye and its 24-h metabolites. The 24-h culture of the dye was centrifuged at $4000 \mathrm{rpm}$ for $20 \mathrm{~min}$, and the supernatant was extracted using ethyl acetate for the analyses. The HPLC analyses were done with a dual $\lambda$ UV-visible detector HPLC (Waters, Austria) on a C18 column (symmetry, $4.6 \times 250 \mathrm{~mm}$ ). The extract was dissolved in HPLC grade methanol, and sample $(10 \mu \mathrm{L}$ of dye or its metabolite) was injected and allowed to separate for $10 \mathrm{~min}$ at the flow rate of $1 \mathrm{~mL} / \mathrm{min}$. A methanol isocratic mobile phase was used. Both MR and its ethyl acetate-extracted metabolites were used in this study. The FTIR spectra of the MR and its metabolites were done using the solid extract on FTIR model 800 (Shimadzu, Japan). The scans were done in the mid-IR region of $400-4000 \mathrm{~cm}^{-1}$ with 16 scan repeat. The samples, mixed with IR grade $\mathrm{KBr}$ in the ratio 10:90, and fixed in a sample holder, were used for the scans.

\subsection{Statistical analysis}

All values were expressed as mean \pm standard deviation (SD) of triplicate observations. Decolorization data were analyzed using the paired samples T test. Statistical analyses were performed using IBM SPSS Statistics version 20. Values were considered statistically significant at $P<0.05$.

\section{Results}

\subsection{Initial screening and identity of the bacterium}

Initial screening of the isolated bacterium showed that the organism could decolorize mixture of dyes containing textile azo dyes Reactive Blue 13, Reactive Yellow 42 and Reactive Red 58. Morphological and biochemical analysis of the isolate showed that it is a gram-negative, rod-shaped, catalase-positive, oxidase-negative, aerobic carbohydrate fermenter. The organism was later identified as a strain of Providencia rettgeri using its $16 \mathrm{~S}$ rRNA gene sequence (Fig. 1); the sequence has been deposited in the NCBI GenBank with accession number GU395555.

\subsection{Decolorization of different concentrations of MR}

To understand the effect of different concentrations of dye on the decolorization ability of the strain, a well-defined and pure laboratory dye, MR was used. The result of the study showed that the initiation of decolorization (lag phase) was prolonged as the concentration increased. The organism showed more than $50 \%$ decolorization of the 10,20 and $30 \mathrm{mg} / \mathrm{L}$ of the dye solution at $3 \mathrm{~h}$; at the end of 6-h incubation time, the $\%$ decolorization was $95.70 \pm 1.64$, $98.00 \pm 1.66,98.03 \pm 78,97.05 \pm 038,82.30 \pm 0.51$ and $26.82 \pm 0.79$ and for $10,20,30,50,100$ and $200 \mathrm{mg} / \mathrm{L}$ solutions, respectively (Fig. 2). We also observed that the organism decolorized the $200 \mathrm{mg} / \mathrm{L}$ MR solution at above $90 \%$ within $12 \mathrm{~h}$ (data not shown). The ability of this strain of $P$. rettgeri to decolorize MR solution at $100 \mathrm{mg} / \mathrm{L}$ within $6 \mathrm{~h}$ is worth noting. Increasing concentration of MR seems to increase the lag phase of the growth and subsequently the decolorization time (Fig. 2). 
Fig. 1 Phylogenetic analysis of $16 \mathrm{~S}$ rDNA sequence of bacterial isolate $P$. rettgeri strain ODO. Distance tree constructed using the neighborjoining method by using MEGA 4. The sequences have been retrieved from $\mathrm{NCBI}$ database, showing the phylogenetic relationships of $P$. rettgeri strain ODO and other species of genus Providencia

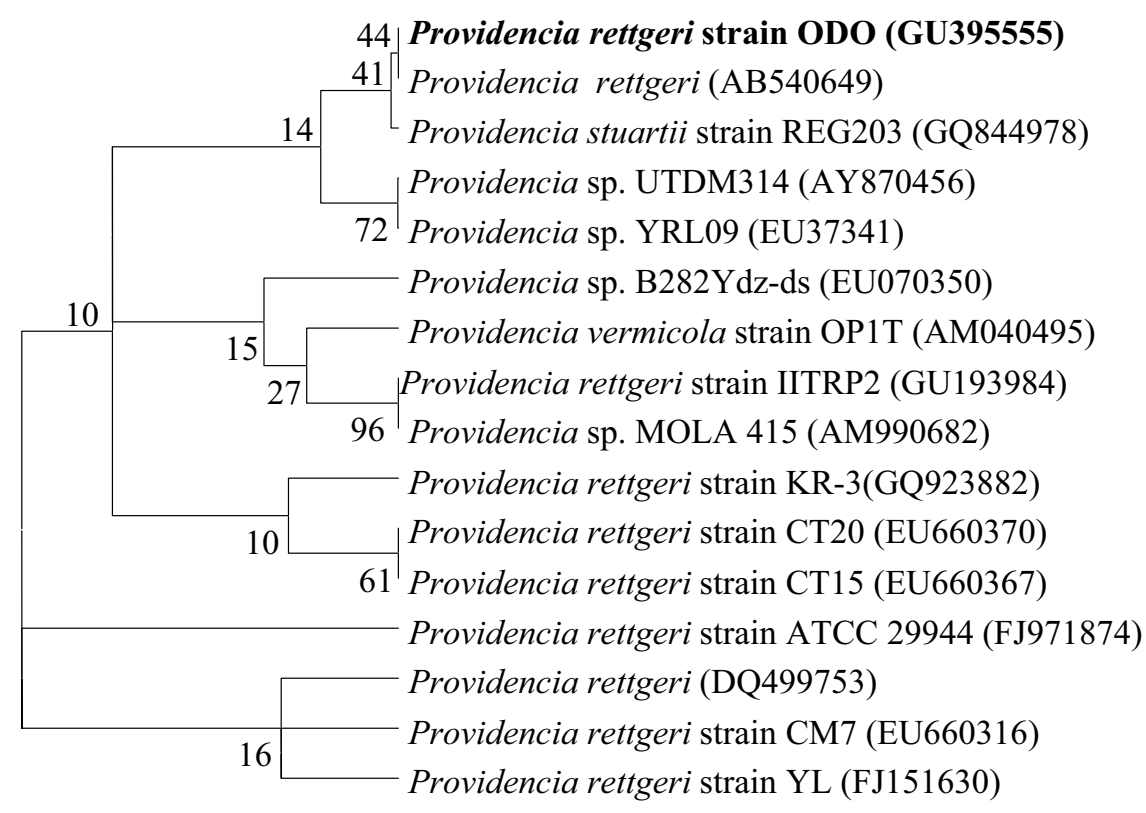

0.01

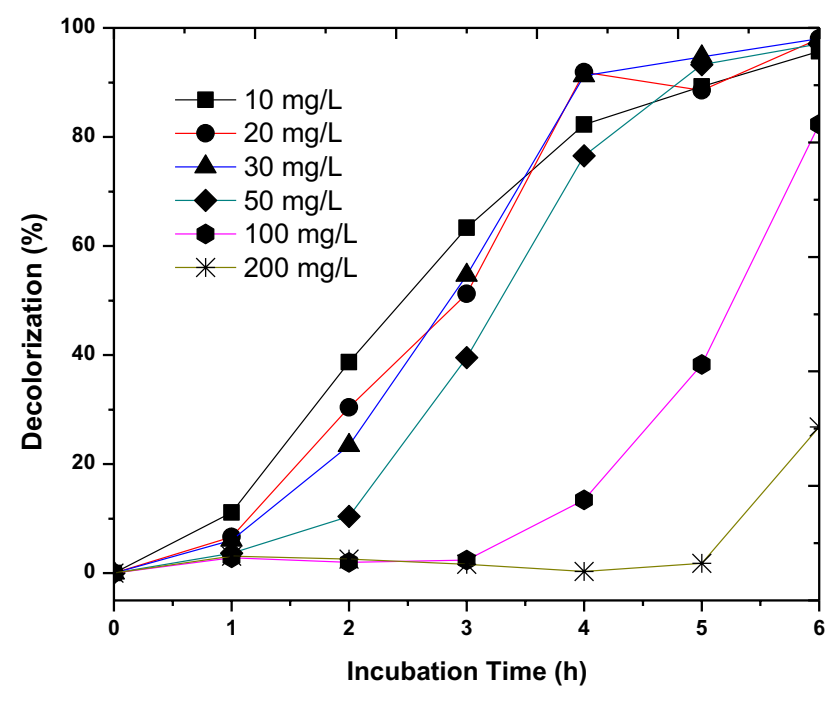

Fig. 2 Effect of initial dye concentration on the decolorization of methyl red by $P$. rettgeri strain ODO

\subsection{Effect of different media on decolorization of MR}

Figure 3 shows the effect of different media types on the decolorization of MR. Among the media types, the most effective decolorization was achieved using nutrient broth with $93.77 \pm 1.05 \%$ decolorization within $6 \mathrm{~h}$. The strain also showed an appreciable level of decolorization when peptone and starch were used as media: $47.74 \pm 1.52$ and $40.76 \pm 0.94 \%$ decolorization, respectively. Yeast and

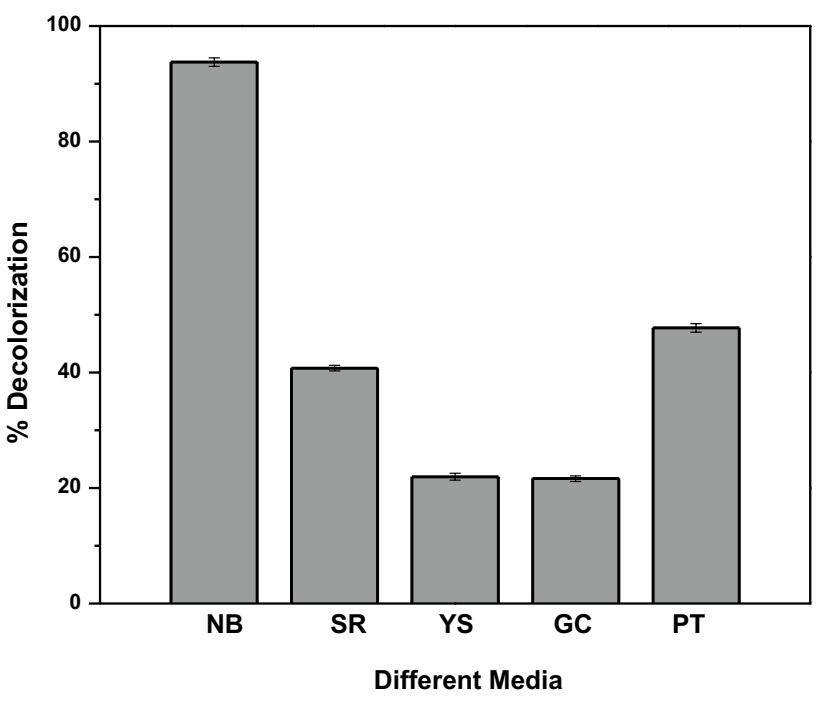

Fig. 3 Effect of various media on the decolorization of methyl red by $P$. rettgeri strain ODO (NB, nutrient broth; SR, starch; YS, yeast; GC, glucose; PT, peptone)

glucose, however, demonstrated a low level of decolorization of $21.94 \pm 0.61$ and $21.64 \pm 0.48 \%$ at the same time of incubation.

\subsection{Effect of redox mediators on the decolorization of MR}

The presence of hydroquinone as mediator showed $94.41 \pm 0.98 \%$ at an incubation time of $5 \mathrm{~h}$, as against 


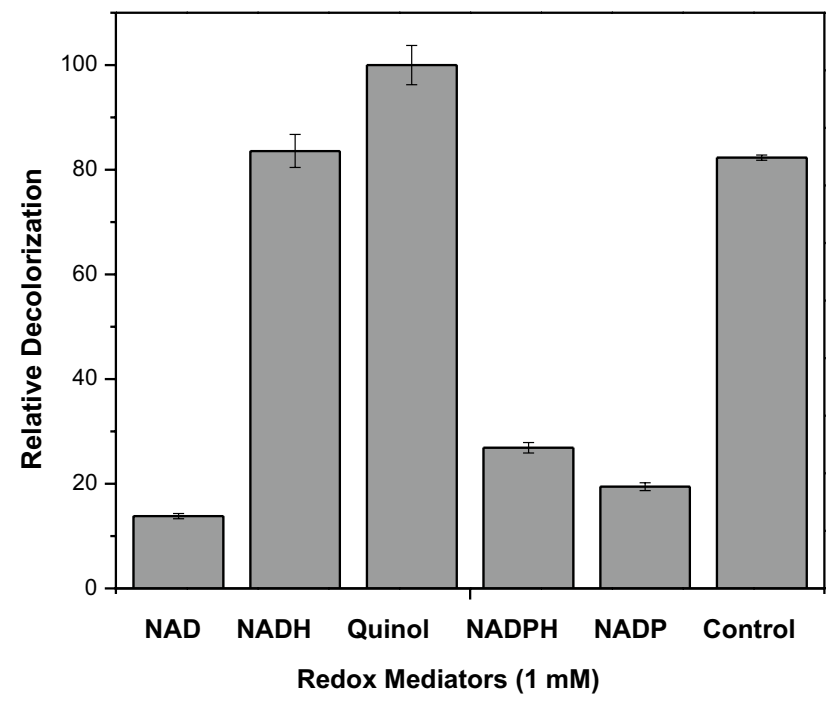

Fig. 4 Effect of redox mediators on the decolorization of methyl red by $P$. rettgeri strain ODO; results after $5 \mathrm{~h}$
$79.35 \pm 1.26$ recorded in the control experiment (dye in nutrient broth without any mediator). Other mediators $\mathrm{NAD}^{+}, \mathrm{NADH}, \mathrm{NADPH}$ and NADP ${ }^{+}$showed 26.86, 19.44, 82.30 and $19.44 \%$ relative decolorization, respectively, when compared to quinol (Fig. 4).

\subsection{Evidence of biodegradation as against mere decolorization}

The UV-visible spectrum showed that absorbance peak of MR at its predetermined $\lambda_{\max }(482 \mathrm{~nm})$ reduced abruptly after $6 \mathrm{~h}$ of incubation. The FTIR spectrum of MR showed specific peaks in the fingerprint region for substituted aromatic compounds $\left(645-831 \mathrm{~cm}^{-1}\right), \mathrm{C}=\mathrm{O}$ stretching at 1621.22 and $\mathrm{C}-\mathrm{H}$ stretching at $2929.00 \mathrm{~cm}^{-1}$. While other peaks were either distorted or removed in the spectrum of the metabolites, there was a sharp increase in the intensity of the peak corresponding to the $\mathrm{C}=\mathrm{O}$ stretching (Fig. 5).
Fig. 5 FTIR analysis of a methyl red and $\mathbf{b}$ its 24-h metabolic products after decolorization by $P$. Rettgeri strain ODO
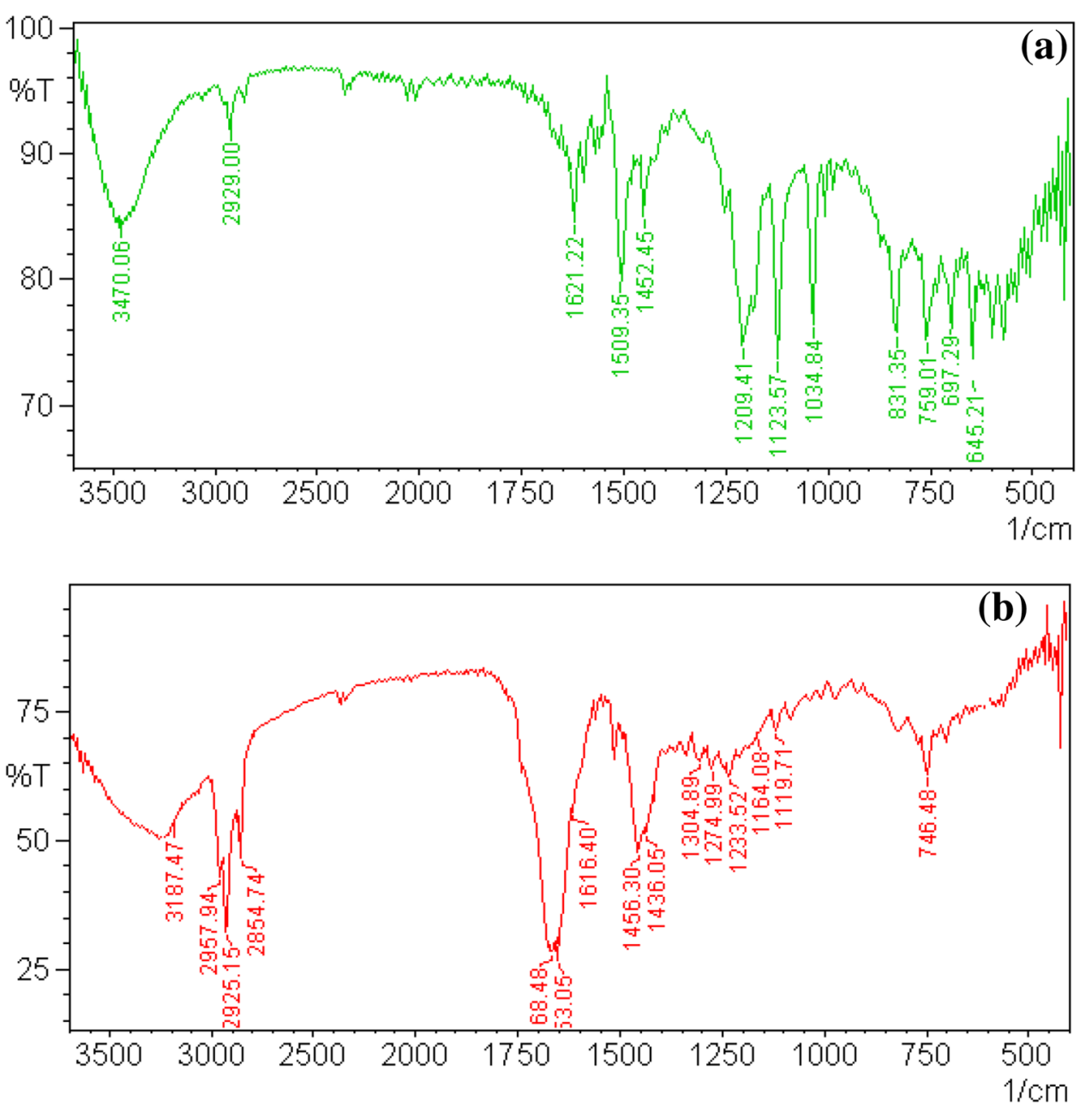

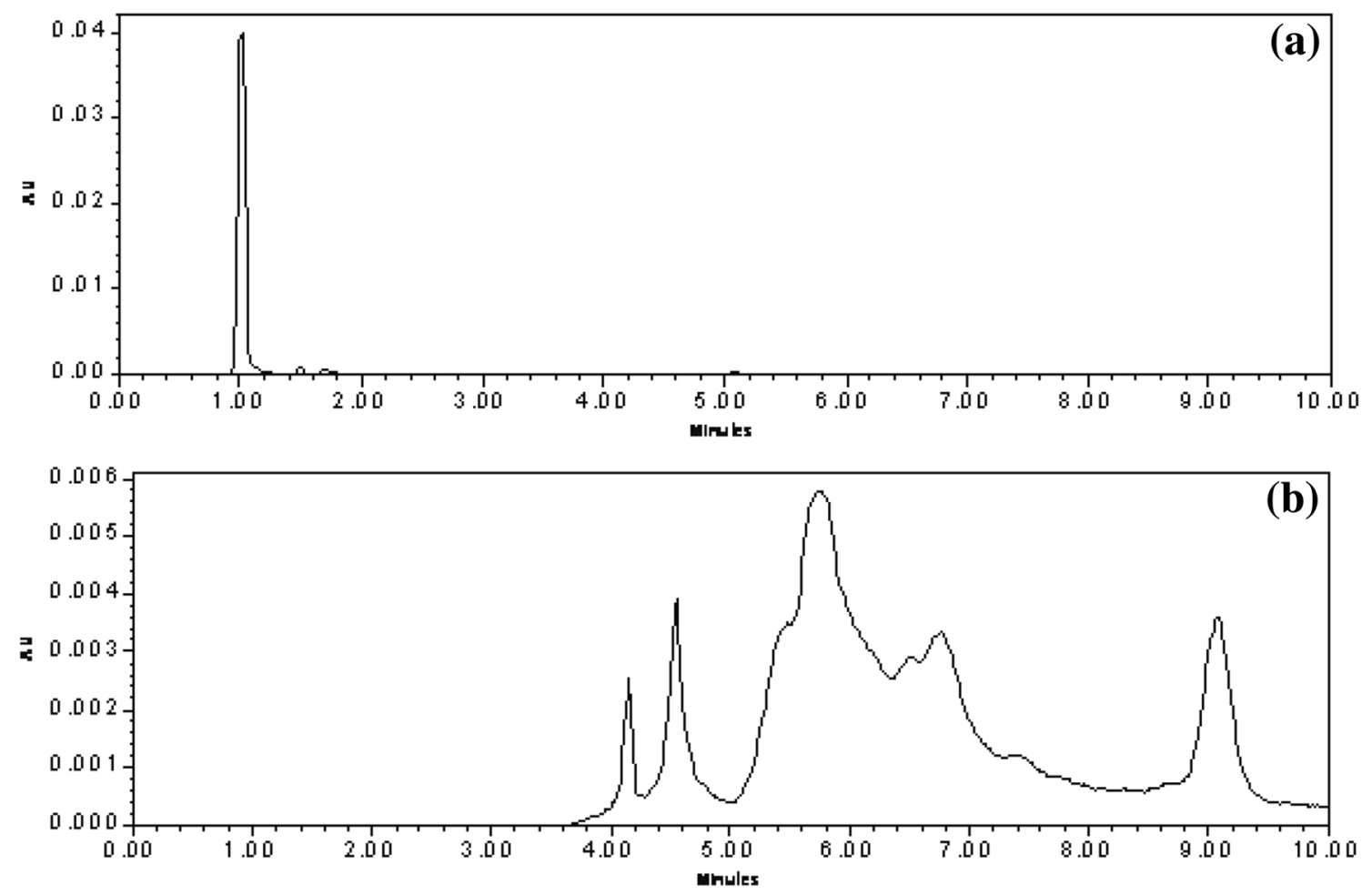

Fig. 6 HPLC analysis of methyl red (MR) (a) and its metabolic products (b) after 24-h decolorization by P. rettgeri strain ODO

The HPLC elution profile of the MR showed a single peak at $11.015 \mathrm{~min}$, as against the several peaks in that of the metabolites (the major ones being at 4.125 and $4.576 \mathrm{~min}$ ). It is also important to note that the absorbance unit (AU) scale of the dye is of the range $0.0-0.04$, while the range was $0.0-0.006$ for the metabolites (Fig. 6).

\section{Discussion}

Generally, the use of chemical mediators in biotreatment serves a dual purpose: firstly to understand the metabolic pathway or mechanism of action of the organism; and secondly to check the possibility of improving reaction rate. In this research, the ability of the mediators to increase the rate of decolorization of MR was investigated.

The result of the $16 \mathrm{~S}$ rRNA gene sequence of the organism showed that the bacterium is a strain of Providencia rettgeri (Fig. 1), and the sequence of the organism was deposited in the NCBI GenBank with accession number GU395555. The ability of this strain of $P$. rettgeri to completely decolorized textile dyes and MR (100 mg/L) under static anoxic condition suggested that it could be useful in wastewater decolorization. Mahalakshmi et al. [21] have observed a similar trend for Congo red, though with algae. Shen et al. [22] also estimated that textile effluents always have dye concentration of about $60 \mathrm{mg} / \mathrm{L}$. The prolonged lag phase experienced as the concentrations of dye increased might be connected with the inhibition of metabolic enzymes' production by the dye molecules, since metabolic enzymes are products of the lag phase [23]. This inhibition of enzyme productions subsequently affected the growth of the organism, thereby preventing the production of the enzyme required for the catabolism of the pollutant, MR.

The fact that the organism preferred NB to other media was an indication that peptone, amino acid and vitamins (which are components of the NB) are required for the decolorization activities. Osuntoki et al. [24] have shown that nutrient sources could enhance biodegradation of pollutants. The preference of hydroquinone among other redox mediators might not be unconnected with the redox potential of the mediator. Forootanfar et al. [25] have reported the increase in decolorization of synthetic and textile dyes in the presence of hydroxybenzotriazole. The reduction in the decolorization time from $6 \mathrm{~h}$ to $5 \mathrm{~h}$ seems significant and economical since a small concentration of the hydroquinone (1 $\mathrm{mM}$ ) was used. However, the hydroquinone concentration needs to be optimized. The decolorization pattern is similar to Michaelis-Menten kinetics, and such trend has been interpreted as probable involvement of enzymes [3]. 
The abrupt reduction in the absorbance value at the $\lambda_{\max }$ after 6-h incubation is an indication of the decolorization and degradation of the dye by the organism $[3,23]$. The disappearance of the peaks at $645.21-831.35 \mathrm{~cm}^{-1}$ and the distortion of that at $759.01 \mathrm{~cm}^{-1}$ (aromatic $\mathrm{C}-\mathrm{H}$ bending) in the FTIR of MR metabolites suggested removal of the aromatic rings of the dyes. Similarly, Jadhav et al. [26] have reported changes in the peaks around $1500 \mathrm{~cm}^{-1}$ as evidence of azo bonds reduction. In this study, there was complete removal of the $1509.35 \mathrm{~cm}^{-1}$ peak in the FTIR of MR metabolites (Fig. 5).

The presence of several peaks in the HPLC profile of MR metabolites and the low $\mathrm{AU}$ values suggested biodegradation rather than mere decolorization. This result differs from studies by Wong and Yuen [27] and Moutaouakkil et al. [28] in which only two peaks corresponding to 2-aminobenzoic acid and $N, N^{\prime}$-dimethyl- $p$ phenylenediamine were products of MR decolorization. The presence of several peaks in the HPLC of the metabolites showed that the dye was degraded to several smaller metabolites. The results of the FTIR analyses further justified the biodegradation, for instance, the disappearance of the $\mathrm{C}-\mathrm{H}$ bending peaks for aromatic rings $\left(600-800 \mathrm{~cm}^{-1}\right)$. The removals of these peaks in the FTIR spectrum of metabolites have been reported as an indication of biodegradation [26]. The findings suggested that this strain of $P$. rettgeri both decolorized and degraded the MR dye.

\section{Conclusion}

This strain of $P$. rettgeri decolorized $100 \mathrm{mg} / \mathrm{L}$ MR within $6 \mathrm{~h}$ and degraded the corresponding aromatic amines formed. Also, it achieved a similar fit with hydroquinone as a redox mediator in $5 \mathrm{~h}$; a rate is considered significant and economically viable since only a small amount $1 \mathrm{mM}$ of the mediator is required. This study, therefore, concluded that this bacterium can be used in the treatment of azo dyes in industrial effluents and that its activities can be increased by using low-cost redox mediator such as hydroquinone for the improvement of the rate of bioremediation.

\section{Compliance with ethical standards}

Conflict of interest On behalf of all authors, the corresponding author states that there is no conflict of interest.

\section{References}

1. Somasiri W, Ruan W, Xiufen L, Jian C (2006) Decolorization of textile wastewater containing acid dyes in UASB reactor system undermixed anaerobic granular sludge. Electron J Environ Agric Food Chem 5:1224-1234

2. Robinson T, McMullan G, Marchant R, Nigam P (2001) Remediation of dyes in textile effluent: a critical review on current treatment technologies with a proposed alternative. Bioresour Technol 77:247-255. https://doi.org/10.1016/S0960-8524(00)00080 $-8$

3. Olukanni OD, Osuntoki AA, Gbenle GO (2006) Textile effluent biodegradation potentials of textile effluent-adapted and nonadapted bacteria. Afr J Biotechnol 5(20):1980-1984

4. Chang JS, Chou C, Chen SY (2001) Decolorization of azo dyes with immobilized Pseudomonas luteola. Process Biochem 36:757-763. https://doi.org/10.1016/S0032-9592(00)00274-0

5. Zollinger H (1991) Syntheses, properties, and applications of organic dyes and pigments: in color chemistry. VCH Publishers Inc., New York, p 496

6. Dubey SK, Pandey A, Bajaj AK, Misra K (2007) Some commercial azo dyes as inhibitors of Mushroom tyrosinase, DOPA oxidase activity. J Pharmacol Toxicol 2:718-724. https://doi.org/10.3923/ jpt2007.718.724

7. Sharma R, Sung SJ, Fu SM, Ju S (2009) Regulation of multi-organ inflammation in the regulatory $T$ cell-deficient scurfy mice. $J$ Biomed Sci 16(1):20. https://doi.org/10.1186/1423-0127-16-20

8. Olayinka KO, Alo BI (2004) Studies on industrial pollution in Nigeria: the effect of textile effluent on the quality of ground waters in some parts of Lagos. Niger J Health Biomed Sci 3(1):44-50. https://doi.org/10.4314/njhbs.v3i1.11507

9. Bafana A, Krishnamurthi K, Devi S, Chakrabarti T (2008) Biological decolorization of C.I. direct black 38 by E. gallinarum. J Hazard Mater 157:183-193. https://doi.org/10.1016/j.jhazm at.2007.12.085

10. Eichlerova I, Homolka L, Lisa L, Nerud F (2005) Orange G and Remazol Brilliant Blue $\mathrm{R}$ decolorization by white rot fungi Dichomitus squalens, Ischnoderma resinosum, and Pleurotus calyptratus. Chemosphere 60:398-404. https://doi. org/10.1016/j.chemosphere.2004.12.036

11. Sarkar S, Banerjee A, Halder U, Biswas R, Bandopadhyay R (2017) Degradation of synthetic azo dyes of textile industry: a sustainable approach using microbial enzymes. Water Conserv Sci Eng 2(4):121-131. https://doi.org/10.1007/s41101-017-0031-5

12. Parshetti GK, Saratale GD, Telke AA, Govindwar SP (2009) Biodegradation of hazardous triphenylmethane dye Methyl Violet by Rhizobium radiobacter MTCC 8161. J Basic Microbiol 49(S1):S36S42. https://doi.org/10.1002/jobm.200800200

13. Fontenot EJ, Lee YH, Matthews RD, Zhu G, Pavlostathis SG (2003) Reductive decolorization of a textile reactive dyebath under methanogenic conditions. Appl Biochem Biotechnol 109:207225. https://doi.org/10.1385/ABAB:109:1-3:207

14. Dos-Santos AB, Cervantes FJ, Van-Lier JB (2004) Azo dye reduction by thermophilic anaerobic granular sludge, and the impact of the redox mediator AQDS on the reductive biochemical transformation. Appl Microbiol Biotechnol 64:62-69. https:// doi.org/10.1007/s00253-003-1428-y

15. Nam S, Renganathan $V$ (2000) Non-enzymatic reduction of azo dyes by NADH. Chemosphere 40:351-357. https://doi. org/10.1016/S0045-6535(99)00226-X

16. Yoo ES (2002) Kinetics of chemical decolorization of the azo dye C.I. Reactive Orange 96 by sulfide. Chemosphere 47:925-931. https://doi.org/10.1016/S0045-6535(02)00068-1

17. Yemashova N, Telegina A, Kotova I, Netrusov A, Kalyuzhnyi S (2004) Decolorization and partial degradation of selected 
azo dyes by methanogenic sludge. Appl Biochem Biotechnol 119:31-40

18. Van der Zee FP, Villaverde S (2005) Combined anaerobic-aerobic treatment of azo dyes -a short review of bioreactor studies. Water Res 39:1425-1440. https://doi.org/10.1016/j.watre s.2005.03.007

19. Tamura K, Dudley J, Nei M, Kumar S (2007) MEGA4: Molecular Evolutionary Genetics Analysis (MEGA) software version 4.0. Mol Biol Evol 24:1596-1599. https://doi.org/10.1093/molbev/msm09 2

20. Stolz A (2001) Basic and applied aspects in the microbial degradation of azo dyes. Appl Microbiol Biotechnol 56:69-80

21. Mahalakshmi S, Lakshmi D, Menaga U (2015) Biodegradation of different concentration of dye (Congo red dye) by using green and blue green algae. Int J Environ Res 9(2):735-744. https://doi. org/10.22059/IJER.2015.947

22. Shen J, Do T, Carwood G, Jenkins R (2002) Biotreatment of textile effluent using Pseudomonas spp. Immobilized on a polymer support. In: Hardin IR et al (eds) Advanced biotechnology for textile processes. The University of Georgia, pp 35-45. http://hdl.handl e.net/2086/1777

23. Olukanni OD, Osuntoki AA, Kalyani DC, Gbenle GO, Govindwar SP (2013) Decolorization of dyehouse effluent and biodegradation of Congo Red by Bacillus thuringiensis RUN1. J Microbiol Biotechnol 23:843-849. https://doi.org/10.4014/jmb.1211.11077
24. Osuntoki A, Awotula A, Olukanni O (2013) Kinetics of the decolorization of a dye house effluent by Providencia rettgeri ODO. Int J Environ Sci 70(4):515-526. https://doi.org/10.1080/00207 233.2013.813794

25. Forootanfar H, Moezzi A, Aghaie-Khozani M, Mahmoudjanlou Y, Ameri A, Niknejad F, Faramarzi MA (2012) Synthetic dye decolorization by three sources of fungal laccase. Iran J Environ Health Sci Eng 9:27. https://doi.org/10.1186/1735-2746-9-27

26. Jadhav JP, Parshetti GK, Kalme SD, Govindwar SP (2007) Decolorization of azo dye methyl red by Saccharomyces cerevisiae MTCC 463. Chemosphere 68:394-400. https://doi.org/10.1016/j.chemo sphere.2006.12.087

27. Wong PK, Yuen PY (1996) Decolorization and biodegradation of methyl red by Klebsiella pneumoniae RS-13. Water Sci Technol 30:1736-1744. https://doi.org/10.1016/0043-1354(96)00067-X

28. Moutaouakkil A, Zeroual Y, Dzayri FZ, Talbi M, Lee K, Blaghen $M$ (2003) Bacterial decolorization of the azo dye methyl red by Enterobacter agglomerans. Ann Microbiol 53:161-169. https:// doi.org/10.1007/s00284-003-4143-0

Publisher's Note Springer Nature remains neutral with regard to jurisdictional claims in published maps and institutional affiliations. 